\title{
Investigation of Science Education in Pre-school Teacher Training Programs in Turkey and Some of the European Union Countries
}

\author{
Nilay KAYHAN ${ }^{* a}$, Didem KILIÇ ${ }^{a}$ \\ ${ }^{a}$ Aksaray Üniversitesi, Eğitim Fakültesi, Aksaray/Türkiye
}

\section{Article Info}

DOI: $10.14812 /$ cufej.2014.014

Article history:

Received 17 March 2013

Revised 18 July 2014

Accepted 29 August 2014

Keywords:

Pre-school education,

Teacher training program,

Science education.

\begin{abstract}
The aim of the present study is to investigate the science courses given within the framework of pre-school teacher training programs in terms of their number, content, variety and credit; hence, a descriptive study to determine the existing state was carried out. The findings were obtained by analyzing the courses included in preschool teacher training programs of the universities reported by each country in their National Education System Descriptions reports. Information concerning the variables of Turkey and European Union Countries was collected from Agencies of the European Union, Eurydice-Network on Education Systems and Policies in Europe. Though there are some differences among the countries in relation to the number, content and time of the science courses given in pre-school teacher training programs, they are not very distinct. With the efforts made to implement accreditation system in the higher education institutions in Turkey within the framework of Bologna adaptation process, it has become compulsory to determine the differences between the programs in Turkey and their counterparts in European Universities. The findings of the present study are believed to make some contributions to the efforts made for the harmonization of Turkish pre-school teacher training programs with European Credit Transfer System.
\end{abstract}

\section{Türkiye ve Bazı Avrupa Birliği Ülkelerinde Okul Öncesi Öğretmenliği Programlarında Fen Eğitiminin İncelenmesi}

\section{Makale Bilgisi}

DOI: 10.14812/cufej.2014.014

Makale Geçmişi:

Geliş 17 Mart 2013

Düzeltme 18 Temmuz 2014

Kabul 29 Ağustos 2014

Anahtar Kelimeler:

Okul öncesi eğitim,

Öğretmen eğitim programları,

Fen eğitimi.

\section{Öz}

Okul öncesi öğretmenliği programlarında yer alan fen eğitimine ilişkin derslerin sayı, içerik, çeşitlilik ve kredileri açısından incelenmesinin amaçlandığı bu çalışmada, var olan durumu belirlemeye yönelik betimsel bir araştırma gerçekleştirilmiştir. Türkiye ve Avrupa Birliğine $(A B)$ üye ülkelerin değişkenlere ait bilgilerine Avrupa Birliği Ajansı, Avrupa Eğitim Bilgi Ağı-Avrupa'da Eğitim Sistemi ve Ulusal Politikalar kaynaklarından ulaşılmışır. Bulgular, araştırmaya dahil edilen ülkelere ait Ulusal Eğitim Sistemlerine Genel Bakış raporlarında referans alınan yükseköğretim kurumlarının okul öncesi öğretmenliği lisans programlarındaki derslerin incelenmesi sonucunda elde edilmiştir. Çalışmada ulaşılan sonuçlara göre, Türkiye ve $A B$ üye ülkelerinin okul öncesi öğretmenliği programlarında yer alan fen eğitimi ile ilgili derslerde kredi ve dönem açısından çeşitlilik görülmekle beraber çok önemli farklılaşmalar bulunmamaktadır. Ülkemizdeki yükseköğretim kurumlarında Bologna uyum süreci ile birlikte akreditasyon sisteminin hayata geçirilmesi, mevcut lisans programlarının $A B$ üye ülkelerindeki eş değer programlarla farklılıklarının belirlenmesini zorunlu hale getirmiştir. Araştırma bulgularının okul öncesi öğretmenliği programında yer alan derslerin Avrupa Kredi Transfer Sistemi (AKTS) ile uyumuna yönelik yapılacak düzenlemelere katkı sağlayacağı düşünülmektedir.

Yazar: nilaykayhan@gmail.com 


\section{Introduction}

In pre-school period, children are highly prone to learning and their curiosity and sense of inquiry are high. For a quality pre-school education, environments promoting children's inquiry and creativity skills and where they can find answers to their questions should be constructed (Aral, Kandır \& Can Yaşar, 2000; EC, 2006; Özbey, 2006). The quality of education given in pre-school period to children when they start to research and investigate their environments has important influences on their academic development as well as on the extent to which they acquire the value judgments of their society. Through activities based on individual and group education, in pre-school period, children gain behavior patterns suitable for the cultural characteristics of the society and they are open to learning; hence, these years are viewed as the years when the basic foundations of the personality are established (Oğuzkan \& Oral, 1997; Ural, 1986).

Pre-school period making up the first step of education system is a period preparing students for their basic formal education. While education programs aiming to enhance children's social, mental, physical and emotional development are implemented starting from age three, these education programs also consider the characteristics brought about by developmental period (Şahin, 1998). Throughout pre-school period, children are curious, inquisitive and questioning. Educational settings where children can create cause and effect relations, satisfy their curiosity, and enhance their prediction skills should be designed. Science activities having potential to contribute to the development of senses of curiosity and investigation may have positive impacts on the creation of quality pre-school settings (Aktaş Arnas, 2003). Science education is considered to be an important field for children continuing their pre-school education. Science education aiming to provide students with activities to arouse their curiosity and lead them to discoveries is carried out in interaction with environment to help them understand objects and events (Özbey, 2006). In pre-school period, science education should be based on the idea that children can learn information better by trying and doing rather than direct transfer of science information (Akt. Arnas, 2002a; 2002b).

Science is considered to be an integral part of our daily life. Science education should be integrated with educational programs by making meaningful connections to daily life (Eliason \& Jenkins, 2003, cited in Uyanık-Balat, 2010). The education programs to be implemented in pre-school period should set objectives and anticipated learning outcomes suitable for all the developmental stages of children. Process of learning by trying and doing consists of activities such as asking questions, making research, collecting data and seeking answers to questions is considered to be the best way of learning science. Basis of a quality science teaching is laid by activities which children actively participate in by doing (Uyanık Balat, 2010). According to Kagan and Kaurez (2006), in a learning process, all the areas of development should be dealt with holistically. While designing educational programs, attention should be paid to making them student-centered, enabling them to make use of their own experiences and carrying out their education in unity (cited in Alabay, 2011). Another factor affecting educational programs is cultural structure. In education systems, it is difficult to design a general science education program in pre-school education considering all cultural differences. Yet, science education programs which children actively participate in, whose objectives are clear and understandable, where teachers make frequent and meaningful contacts with children, which are based on evidence and consider the prior learning experiences and which are in compliance with learning standards and proper evaluation programs can be developed (Alabay, 2011).

An effective science education should be considered as a whole with the qualities of its programs and application process. The success of the designed educational programs is connected with the professional skills of teachers. Teachers conduct different activities to realize the objectives and anticipated learning outcomes of the programs. Science activities directing students to observation, research, analysis and discovery are one of these activities (MEB, 2012b). Main role should be assumed by teachers to present science courses in a manner suitable for the development of children (Kallery, 2004). When studies looking at the science education activities conducted in pre-school period are examined, it is seen that Kallery and Psillos (2001) carried out a study with 12 pre-school teachers 
working in Greece and they found that in early childhood period, it is of great importance to answer the questions of children; yet, only $21.9 \%$ of the teachers could answer to questions based on science and scientific activities within a conceptual framework. Ayvacı, Devecioğlu, and Yiğit (2002) found that the pre-school teachers are not qualified enough to carry out science activities at the desired quality level, they cannot develop original materials; Bilaloğlu, Aslan, and Aktaş Arnas (2008) stated that they cannot incorporate enough science activities into their daily programs, they cannot capitalize on informal learning experiences, and they are inadequate in applying the teaching methods they know while planning their science activities. It was also found that the method used most frequently by pre-school teachers is experiment method and concept-maps and analogies are not used by them (Şahin, 1996).

In pre-school education program, it is argued that characteristics of the teacher are one of the most important factors affecting the development of the child (MEB, 2008; 2012a). Pre-school teachers are engaged in the establishment of different learning centers and activities so that they can go through the processes of preparation and evaluation of education plans. Learning centers are play areas including various materials designed in line with the objectives and anticipated learning outcomes of the course. These areas are separated from each other by means of materials such as book cases, bulletin boards, carpets with different colors, floor coverings or tapes stuck on the floor. Physical structure of the classroom may include learning centers, block centers, book centers, music centers, art centers, dramatic play centers and science centers designed considering the developmental period and individual characteristics of students. Learning centers can be a great aid to the creation of good designed educational centers and development of creative problem solving skills by promoting the effective learning of students. Each learning center can contribute to the realization of different learning outcomes and a science center in elementary education program should be designed by considering children's curiosity about the world and willingness to learn what is happening around them. The science center aiming to arouse children's curiosity, promote their desire to learn and encourage them to learn new things about the world should be designed in such a way as to help children to acquire scientific process skills and work comfortably in a quiet environment (MEB, 2012a). Another component of pre-school education program is activities. In the program, there are "Turkish language teaching, art, drama, music, game, science, mathematics, reading and writing preparation and field trip" activities. Science activities are defined as activities leading students to paying attention, asking question, wondering, making observations, researching, analyzing and discovering. Primary aim of science activities through which children are introduced to realities of life in pre-school period is to raise children's awareness of their environment. The activities planned considering the developmental characteristics of children should be designed to provide children with opportunities to acquire scientific process skills. Throughout the process, for children to develop proper attitudes towards their environment and display desired behaviors, their teachers' attitudes should be appropriate (MEB, 2012a).

In order to be able to give a quality science education to pre-school children, teachers should be equipped with sufficient knowledge of different components of science education such as physics, biology, chemistry etc. (Kallery, 2004). Science education given at pre-school period which will have a great influence on their future success will also be able to affect science achievement in the further stages of their education. When children live negative experiences during pre-school period in which they encounter with their first science activities and if they are not supported by their teachers, they may develop negative attitudes towards science. Hence, investigation of the knowledge and competency level of pre-service science teachers about science education may yield precious information to improve pre-school children's academic achievement and their attitudes towards science (Simpson \& Oliver, 1990).

Pre-school teachers' information level about science education affects works to be done to design and evaluate lesson plans. Pre-school teachers having limited information about science education were found to have some difficulties in recognizing children's conceptual fallacies and in making satisfactory explanations about the topic (Osborne \& Simon, 2001). Kallery (2004) carried out a study to investigate 
pre-school teachers' opinions about science education and found that the teachers having inadequate information about science education experience some difficulties while making explanations to children and feel anxious about science teaching. It was also found that the teachers thinking that they do not have enough information about science education include relatively fewer science activities in their daily lesson plans. Another study looking at pre-school teachers' opinions about science education was conducted by Özbek (2009). The pre-school teachers participating in this study stated that science education at early ages is important and the most common method they use is experiment and it is followed by drama, field trip and observation methods.

Educational policies implemented affect social and cultural developments and economic growth of countries. In societies in which socio-cultural and economic characteristics are changing rapidly as in Turkey, paying attention to the care and education of children at early ages will result in many positive outcomes for the society in the long-term (Ural \& Ramazan, 2007). During the first years of their life, providing students with quality teaching environments is an important indicator of the developmental level of a country; hence, the quality of the teachers educating children at these early years of great importance. There is a need for some innovations and changes for teacher training institutions to attain a certain level of standardization in our country. In order to be able to make these changes, it would be useful to analyze the education systems and policies of the European Union member countries.

Investigation of the science education given in pre-school teacher education programs implemented in Turkey and European Union countries in terms of credits, number, variety and content of the courses will yield important findings to evaluate the pre-school teacher education programs in Turkey. However, there is no study in the literature investigating the science teaching courses in the programs of preschool teacher training by comparing them with the similar courses given in European Union member countries in terms of number, credit and content. Therefore, the present study investigated the science teaching courses given in pre-school teacher training programs in Turkey by comparing them with the science teaching courses offered in pre-school teacher training programs of some European Union countries. These findings can have important contributions to the design of science education given in pre-school teacher education programs and also to the arrangements to be made for the compliance of the courses in pre-school teacher education programs with European Credit Transfer and Accumulation System (ECTS).

\section{Method}

\section{Research Design}

In the present study aiming to investigate the science education given in pre-school teacher education programs implemented in Turkey and European Union countries in terms of credits, number, variety and content of the courses, a descriptive research aiming to determine the current state was conducted. In the present study in which document analysis method was employed (Yıldırım \& Şimsek, 2006), the data considering the variables of Turkey and European Union countries were collected from European Agency, Information Network on Education in Europe and Network on Education Systems and Policies in Europe (Eurydice). The findings were obtained through the analysis of the pre-school teacher education undergraduate courses stated in the National System Overviews reports issued by each country. The course programs and course content issued in the web-sites of the universities referred to by these reports were analyzed and then the data were comparatively described in terms of the academic year and term of the course, the number of courses, their content and credits.

In order to determine the courses related to science education, Information Network on Education in Europe and Network on Education Systems and Policies in Europe (Eurydice), where each country issue their national education report, were reached through the web site of European Agency. From these reports issued by each country, the web addresses of the referred institutions of higher education were obtained. By examining the institutions of higher education from their web sites, "kindergarten teacher 
education, pre-school teacher education and early childhood education" programs of these institutions were determined. The courses taken at these programs, their syllabi, required courses, conditions to be fulfilled to graduate, and annual academic calendar were systematically analyzed. The pre-school teacher education program of each country was examined in terms of total education period, conditions of entry to the program, conditions to be fulfilled to graduate, required courses, diversity of courses, ECTS credit of each course, its content, and teaching and the data collected in this way were converted into findings in line with the purposes of the study. All the data constituting the findings are obtained from the analysis of the national education reports where teaching programs of the pre-school teacher education institutions are explained in detail. The data of the study is limited to some of the European Union countries, which reported their national educational report from European Agency, Information Network on Education in Europe or Network on Education Systems and Policies in Europe (Eurydice).

\section{Results}

\section{System of Pre-school Teacher Education in Turkey}

In line with the article 43 of no 1739 National Education fundamental law, the pre-school teacher education is under the responsibility of higher education intuitions. Two-year "Kindergarten teacher" education program initiated in 1980-1981 was converted into 4-year program and put under the supervision of education faculties as of 1991-1992 school year. Then its name was changed into "Preschool Teacher Education" and with the Higher Education Council's attempts to restructure education faculties in 1998, it was accepted as a department in elementary school education programs of education faculties. With this amendment, Higher Education Council brought standardization to preschool teacher education given both at state universities and foundation universities. According to the data issued by Higher Education Council Student Selection and Placement Center for 2012, there are 62 state universities and 13 foundation universities; totally 75 universities, offering pre-school teacher education programs (YÖK, 2012a).

In Turkey, synchronous model is followed in pre-school teacher education program, and the courses of general knowledge, subject area and pedagogy are presented in integrity. In order to be able to enter the program, one should have a high school diploma and get the required score form higher education entrance exam. The students have to complete 240 ECTS at the end of four academic years and then they can graduate from the department with a bachelor degree (YÖK, 2012b). Then the students have to enter State Personnel Selection Exam and if they get the required score then they can be recruited as a pre-school teacher by the Ministry of National Education. There is certain number of teaching posts for each subject area; hence, there is a cut point and those who get scores higher than this cut point can be appointed to these posts. In its current form, the total score is determined by the sum of the scores taken from "General Ability", "General Culture" and "Educational Sciences" sub-tests of KPSS exam. Yet, the Ministry of National Education declared that as of 2013, the candidates might have to answer the questions from their own subject area (MEB, 2012b).

\section{Courses related to Science Education in Pre-school Teacher Education Programs of Turkey and European Union Countries}

The number of the courses related to science education in pre-school teacher education programs of Turkey and some of the European Union countries and their distribution according to years are presented in Table 1. 
Table 1. The Number of the Courses Related to Science Education in Pre-school Teacher Education Programs of Turkey and Some of the European Union Countries

\begin{tabular}{lccccc}
\hline Countries & $1^{\text {st }}$ year & $2^{\text {nd }}$ year & $3^{\text {rd }}$ year & $4^{\text {th }}$ year & Total \\
\hline Austria & - & 2 & - & - & 2 \\
Belgium & - & 1 & - & - & 1 \\
Cyprus & - & 1 & 1 & - & 2 \\
Denmark & - & 2 & - & - & 2 \\
Finland & 1 & 1 & - & - & 2 \\
Greece & 1 & 2 & 1 & - & 4 \\
Holland & 1 & - & 1 & - & 2 \\
Hungary & 3 & 1 & 1 & - & 5 \\
Ireland & - & - & 2 & - & 2 \\
Lithuania & 1 & 1 & 1 & 1 & 4 \\
Luxemburg & 1 & 1 & 1 & - & 3 \\
Malta & 3 & 2 & - & 2 & 7 \\
Poland & - & 1 & 1 & - & 2 \\
Portugal & 1 & 1 & 2 & - & 4 \\
Slovenia & 1 & 1 & 1 & - & 3 \\
Spain & 1 & - & 1 & - & 2 \\
Sweden & 1 & 1 & - & - & 2 \\
The Czech Republic & 3 & - & - & - & 3 \\
Turkey & 2 & 2 & 1 & - & 5 \\
\hline
\end{tabular}

In Table 1, the number of the required courses related to teaching of science in pre-school teacher education programs of Turkey and some of the European Union Countries and their distribution according to academic years can be seen. In Lithuania, there is one required course related to science teaching in each of the four year. In Hungary, Greece, Luxemburg, Portugal, Slovenia and Turkey, there are required courses related to science teaching in the first three academic years. When the total number of the required courses related to science teaching was investigated in the programs, it was found that there are seven courses in Malta, five courses in Turkey and Hungary, four courses in Greece, Lithuania, and Portugal, three courses in the Czech Republic, Luxemburg and Slovenia, two courses in Austria, Denmark, Finland, Holland, Ireland, Spain, Sweden, South Cyprus and Poland and one course in Belgium.

Total ECTS credits of the courses related to science education in pre-school teacher education programs of Turkey and some of the European Union countries are presented in Table 2.

As can be seen in Table 2, there is a variety among the credits and terms of the courses related to science teaching in pre-school teacher education programs of the countries. Besides, no significant differentiation in terms of the credit ratio of the credits of the science teaching courses in total credits of all the courses to be taken is observed between Turkey and European Union countries. In general, it is seen that the proportion of the courses related to science education accounts for $6 \%$ to $10 \%$ of all the course credits to be taken. For instance, in Austria, there are totally 30 credits of science courses given in second year of pre-school teacher education program under the names of "Sing, Play and Explore" and "Health, Nutrition for Children" and the credits of these two courses make up 6\% of the total 480 credit-program consisting of totally 32 courses. In South Cyprus, there are two five-credit courses "Science Education in Early Childhood Education" and "Childhood Health, First Aid and Safety" in a fourstage undergraduate program of totally 240 credits. First of these five-credit course is given at "Level B" and constitutes $6 \%$ of the total 83 credits that should be taken and the second one is given at "Level C" and constitutes $10 \%$ of total 51 credits that should be taken. In Turkey, there are five courses related to science education in the pre-school teacher training programs. These courses are distributed across the academic years as follows: first year, 8-credit "Mother and Child Health and First Aid" and 5-credit "Human Anatomy and Physiology"; second year, 4-credit "Mother and Child Nutrition" and 5-credit 
"Creativity and Its Development" and finally, third year, 4-credit "Science Teaching". The total number of credits of all these courses is 26 and the total number of credits to be taken to graduate from the program is 240 ; hence, their proportion is nearly $10 \%$.

Table 2. ECTS Credits of the Courses Related to Science Education in Pre-School Teacher Education Programs of Turkey and Some of the European Union Countries

\begin{tabular}{|c|c|c|c|c|c|}
\hline Countries & $1^{\text {st }}$ year & $2^{\text {nd }}$ year & $3^{\text {rd }}$ year & $4^{\text {th }}$ year & ECTS credits (Total) \\
\hline Austria & - & 30 & - & - & 30 \\
\hline Belgium & - & 1 & - & - & 1 \\
\hline Cyprus & - & 5 & 5 & - & 10 \\
\hline Denmark & - & 6 & - & - & 6 \\
\hline Finland & 3 & 3 & - & - & 6 \\
\hline Greece & 3 & 7 & 3 & - & 13 \\
\hline Holland & 3 & - & 3 & - & 6 \\
\hline Hungary & 4 & 2 & 1 & - & 7 \\
\hline Ireland & - & - & 30 & - & 30 \\
\hline Lithuania & 5 & 4 & 7 & 3 & 19 \\
\hline Luxemburg & 3 & 3 & 3 & - & 9 \\
\hline Malta & 12 & 8 & - & 8 & 28 \\
\hline Poland & - & 6 & 1 & - & 7 \\
\hline Portugal & 10 & 5 & 10 & - & 25 \\
\hline Slovenia & 5 & 7 & 4 & - & 16 \\
\hline Spain & 3 & - & 3 & - & 6 \\
\hline Sweden & 30 & 30 & - & - & 60 \\
\hline The Czech Republic & 7 & - & - & - & 7 \\
\hline Turkey & 13 & 9 & 4 & - & 26 \\
\hline
\end{tabular}

The credits of the science-related courses in the European Union countries included in the present study vary from 1 to 60. In Ireland and Austria, there are two required science teaching courses, each of them having 15 credits. In Sweden, students take two courses each of which is 30 credits in the first and second years of their undergraduate education. In Belgium, there is only one science-related course that is only one credit. On the other hand, in many European Union countries such as the Czech Republic, Cyprus, Denmark, Finland, Holland, Hungary, Lithuania, Luxemburg, Malta, Portugal, Slovenia, and Spain and also in Turkey, the credits of science teaching courses given in pre-school teacher education programs accounts for between 2 and 10 ECTS credits.

Findings concerning the content of the courses related to science education in pre-school teacher training programs of the countries are presented in Table 3.

As can be seen in Table 3, the science-related courses given in pre-school teacher education programs of Turkey and some of the European Union countries focus on similar topics such as basic principles of science education, its basic concepts, environmental problems and environmental awareness, health education, first-aid, science and technology, development of science process skills, community health, anatomy, and ecologic balance. While there are courses dealing with science and technology relation and the effects of technology on environment in pre-school teacher education programs of Denmark, Holland, Lithuania and Malta, courses primarily aiming to develop science process skills are given as a required course only in the pre-school teacher education program of Hungary. 
Table 3. Content of the Courses Related to Science Education in the Pre-school Teacher Training Programs of Turkey and Some of the European Union Countries

\begin{tabular}{|c|c|c|c|c|}
\hline \multicolumn{5}{|c|}{ Course content } \\
\hline Countries & $1^{\text {st }}$ year & $2^{\text {nd }}$ year & $3^{\text {rd }}$ year & $4^{\text {th }}$ year \\
\hline Austria & - & $\begin{array}{l}\text { Health education and } \\
\text { creativity }\end{array}$ & - & - \\
\hline Belgium & - & $\begin{array}{l}\text { Health education and } \\
\text { first aid }\end{array}$ & - & - \\
\hline Cyprus & - & Science education & $\begin{array}{l}\text { Science and } \\
\text { environment } \\
\text { education }\end{array}$ & - \\
\hline Denmark & - & $\begin{array}{c}\text { Health education } \\
\text { Science, technology and } \\
\text { nature relation }\end{array}$ & - & - \\
\hline Finland & Health education & $\begin{array}{c}\text { Science education } \\
\text { Environment education }\end{array}$ & - & - \\
\hline Greece & Science education & $\begin{array}{c}\text { Science and nature } \\
\text { education } \\
\text { Child diseases }\end{array}$ & Science education & - \\
\hline Holland & Science education & 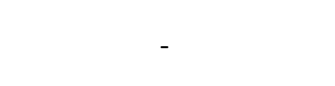 & $\begin{array}{l}\text { Technology and } \\
\text { ecologic balance }\end{array}$ & - \\
\hline Hungary & $\begin{array}{c}\text { Function of organism } \\
\text { Environmental problems } \\
\text { Ecologic balance } \\
\text { Environment education }\end{array}$ & Scientific process skills & $\begin{array}{l}\text { Basic principles of } \\
\text { science education }\end{array}$ & - \\
\hline Ireland & - & - & $\begin{array}{l}\text { Science and } \\
\text { environment } \\
\text { education }\end{array}$ & - \\
\hline Lithuania & Child health and diseases & $\begin{array}{c}\text { Play and creativity in } \\
\text { education }\end{array}$ & $\begin{array}{l}\text { Technology in pre- } \\
\text { school education }\end{array}$ & $\begin{array}{c}\text { Environment } \\
\text { education and } \\
\text { ecologic balance }\end{array}$ \\
\hline Luxemburg & $\begin{array}{l}\text { Introduction to natural } \\
\text { sciences }\end{array}$ & $\begin{array}{c}\text { Community health, } \\
\text { ways of protection from } \\
\text { diseases }\end{array}$ & $\begin{array}{l}\text { Child health and } \\
\text { diseases }\end{array}$ & - \\
\hline Malta & $\begin{array}{l}\text { Science and technology } \\
\text { Science teaching }\end{array}$ & $\begin{array}{l}\text { Health education } \\
\text { School health } \\
\text { Preparation to science } \\
\text { and math teaching }\end{array}$ & - & $\begin{array}{l}\text { Science and } \\
\text { technology } \\
\text { Play and } \\
\text { education }\end{array}$ \\
\hline Poland & - & Basic concepts & $\begin{array}{c}\text { Environment } \\
\text { education }\end{array}$ & - \\
\hline Portugal & Natural sciences 1-2 & Anatomy & $\begin{array}{c}\text { Environment } \\
\text { education }\end{array}$ & - \\
\hline Slovenia & $\begin{array}{c}\text { Basic principles in science } \\
\text { teaching }\end{array}$ & $\begin{array}{c}\text { Science and } \\
\text { environmental } \\
\text { awareness }\end{array}$ & $\begin{array}{l}\text { Play in science } \\
\text { education }\end{array}$ & \\
\hline Spain & Child health and diseases & Environment education & - & - \\
\hline Sweden & Science and social sciences & $\begin{array}{l}\text { Scientific developments } \\
\text { and culture relation }\end{array}$ & - & - \\
\hline The Czech & Introduction to biology & & & \\
\hline Republic & $\begin{array}{l}\text { Health education } \\
\text { Introduction to biology }\end{array}$ & - & - & - \\
\hline Turkey & $\begin{array}{l}\text { Organism and life } \\
\text { Mother-child health and } \\
\text { first aid }\end{array}$ & $\begin{array}{l}\text { Mother-child feeding } \\
\text { Development of } \\
\text { creativity }\end{array}$ & Science education & - \\
\hline
\end{tabular}


The credits of the science-related courses in the pre-school teacher education programs of Poland, Portugal, Greece, Czech Republic, Hungary, Lithonia and Sweden are divided into two parts being practical and theoretical. The pre-school teacher education program in Denmark is under the influence of the education philosophy based on multiculturalism and social support. In the program, in which "health education" and "science and nature" courses are required, the pre-school pre-service teachers have to work with children from different cultures and ethnic origins. In Spain and Portugal there are courses aiming to teach pre-service teachers how to prevent school accidents from happening. When the contents of the courses are investigated in general, it is seen that there are similar topics taught and first-year students take courses dealing with topics such as mother-child health, functioning of organism, and healthy diet in pre-school teacher education programs in Czech Republic, Finland, Hungary, Lithuania, Spain and Turkey.

In the first year of the pre-school teacher education programs of the countries such as Greece, Holland, Luxemburg, Malta, Portugal, Slovenia and Sweden, basic principles and concepts of science education are taught. While courses aiming to improve creativity are given in the second year of the pre-school teacher education programs of countries such as Austria, Lithuania and Turkey, such course is given in the first year in Malta. When the content of the creativity development course given in the pre-school teacher training programs of European Union countries and Turkey is examined, it is seen that great importance is attached to the frequent use of experiments and field trips for students to be good observers and their providing guidance for children to raise animals, grow plants, conduct experiments and conduct research so that children's curiosity about nature can be nurtured. As science education provides opportunities to learn by doing and experiments and observations support the talent of explore, the course related to creativity is dealt with in the context of science education as in other European Union countries. Besides it is notable that the content of science-related courses given in Holland, Hungary and Portugal focuses on the relations between science and technology and culture. Among the countries included in the present study, only in Lithuania and Malta, there are courses related to science education in the fourth year. While there are no courses dealing with environmental education, ecologic balance, environmental problems, harmful effects of technological advancements on nature in the pre-school teacher education program of Turkey, there are required courses given in the second and third years about environmental awareness, sensitivity to environment and importance of environmental education in the pre-school teacher education program of many European Union countries such as Cyprus, Denmark, Greece, Holland, Hungary, Ireland, Lithuania, Malta, Poland, Portugal, Slovenia and Spain.

\section{Discussion, Conclusion \& Implementation}

The experiences gained by pre-service teachers during their university education have important influences on their professional applications and competencies. However, for the competencies in subject area teaching, subject area competency is considered to be a pre-requisite (Garbett, 2003). For a pre-school teacher to gain these competencies, information, skills and attitudes acquired during educational and instructional process are of great importance. Investigation of teacher education programs of higher education institutions in terms of their courses and content of the courses may reveal important findings related to competencies pre-service teachers are expected to acquire.

While there are similarities between the pre-school teacher education programs of Turkey and some of the European Union countries in terms of length of education, degree to be granted, diversity and content of courses, there are some differences in terms of ECTS credits of the science teaching related courses. While in Holland, Portugal, Slovenia and Turkey, the ECTS number of the courses vary between 2 and 10; in Sweden, there are two 30-credit courses, "Science and Social Studies in Early Childhood-I" and "Science and Culture Education in the Preschool School", so the total credit of these courses is 60. On the other hand, it is seen that in some of the European Union countries such as Greece, Hungary, Lithuania, Luxemburg, Malta and Sweden, with the increasing number of science-related courses in pre- 
school teacher education programs, the number of the ECTS credits assigned to these courses decreases. In Lithuania the credit number of 4 science-related courses is 19, in Luxemburg, there are 3 science teaching courses with total credit number of 9, in Hungary, there are 5 courses with the total credit of 7, in Malta, there are 7 courses with the total credit number of 28 and in Greece, there are 4 courses with the total credit number of 13 . On the other hand, though there are fewer science teaching courses (two courses) in Ireland and Sweden, their total credit number is higher (30 ECTS in Ireland, 60 ECTS in Sweden).

All the pre-school education programs investigated in the present study are undergraduate programs which last 7 to 9 terms and the total ECTS credits to be taken to graduate range from 180 to 240 . While the total ECTS credit required to graduate is 240 in Malta, Lithuania, Luxemburg, Portugal, Spain and Turkey, it is 180 in Greece, Hungary, Ireland, and Slovenia. Having similar required courses, the preschool teacher education programs in Czech Republic, Holland, Hungary, Ireland, Lithuania, Portugal require their students to complete 240 ECTS credits in a four-year period to graduate; yet, in Greece, total ECTS credits to be taken to graduate is 180 . On the other hand, in Sweden, pre-school teacher education program last three years but requires taking totally 210 ECTS.

When the total credit numbers of the science-related courses given in pre-school teacher education programs of the countries were compared, following results were obtained: in Turkey, with the total 240-credit (127 theoretical, 48 practical) pre-school teacher education program, there is a sciencerelated course "Human Anatomy and Physiology" with 5 ECTS credits given in the $1^{\text {st }}$ term, "Motherchild Health and First-aid" course with 8 ECTS credits given in the $2^{\text {nd }}$ term, "Mother and Child Feeding" course with 4 ECTS credits and "Creativity and Its Development" course with 5 ECTS credits given in the $3^{\text {rd }}$ term and "Science Education" course with 4 ECTS credits given in the $5^{\text {th }}$ term. It is seen that the total credits of the science-related courses constitute $10 \%$ of the total credits to be taken to graduate. In Turkey and European Union countries, in the pre-school teacher education programs, instruction of plays, creativity and environmental education are given within the science-related courses. For instance, in Slovenia "Children's Play and Research in Natural Environment (4 ECTS)", in Austria, "Sing, Play and Explore (15 ECTS)" aim to teach how to design games related to teaching of basic principles of science education, creativity, environmental education and natural phenomena.

In many of the European Union countries (Czech Republic, Denmark, Holland, Spain, Sweden, Lithuania, Luxemburg, Hungary, Greece) apart from the required courses, there are elective courses given in the fields of science and technology, mathematics, and language. In Denmark, pre-school student teachers have to complete a project of competence to seek for an answer to the question "how should the subjects of human health, natural phenomena, interaction with environment be taught to pre-school children?" to graduate. Students attending pre-school teacher education programs in Luxemburg and Czech Republic have to prepare social responsibility projects on the topics such as health, feeding and ecologic balance and work in cooperation with non-governmental organizations. In Greece, students attending pre-school teacher education programs take courses on genetics, hereditary diseases, child diseases and prepare projects of competency on the development of scientific process skills.

Both in Turkey and in some of the European Union countries, there are courses in pre-school teacher education programs to train pre-service teachers about the development of materials to teach the basic principles of science education, technological advancements, scientific process skills, creativity and play and natural phenomena. Particularly in recent years, with the increasing amount of unhealthy feeding, unhealthy feeding-based diseases are on the increase and pre-school period is of great importance to train students to avoid such diseases. For this purpose, there are courses in pre-school teacher education programs dealing with the issues such as healthy diet, mother-child health, ways of protection from diseases and treatments of diseases. In this way, pre-school education can contribute to the creation of healthy generations. Other important issues incorporated into the curriculums of preschool education are accidents, first aid and risk factors. In pre-school period when the curiosity is high, children should be instructed about the ways of avoiding daily accidents. In pre-school teacher 
education programs, there are courses aiming to instruct pre-service teachers about development of the concept of play in children and play in a learning setting and first aid to prevent possible future school accidents.

There are some changes resulting from Bologna process in higher education institutions. When these changes are examined in terms of pre-school teacher education programs, it is seen that there are some important changes taking place in some European Union countries such as Austria and Malta and as a result of these changes, their requirements for graduation somehow changed in 2011. For instance, preschool teacher education program in Malta extended to four years from two years and in Austria, while it had been vocational education degree program, it was turned into undergraduate education program.

The content of the required courses given during the undergraduate education of pre-service teachers has some important influences on the determination of their subject area self-efficacy. As pre-school education constitutes a period in which children can acquire basic science concepts and develop positive or negative attitudes towards science and technology, it is of great importance to train qualified preschool teachers. Hence, the contents of the courses given in pre-school teacher education programs should be designed well enough for pre-school teachers to acquire the required qualifications (Alabay, 2006). The common result revealed by the research on child education is that when enough opportunities are provided, they can carry their development to the highest possible point. Pre-school teachers should assume an important responsibility for creating settings which allow children to maintain their development in an effective manner. In the construction of learning settings in pre-school period, in the provision of effective science education, attitudes of teachers are as important as their subject area knowledge. Interdisciplinary planning should be performed in content and credit arrangements of the courses in pre-school teacher education programs and it should be considered that the number and content of the courses related to science and mathematics teaching may have some influences on pre-service teachers' perceptions of science and mathematics. In addition to theoretical contents of the courses in pre-school teacher education programs, the weight of their practical parts should be considered. And the undergraduate pre-school teacher education program should be designed to enable pre-service teachers to acquire the necessary theoretical and practical information and skills. These target skills and information are taken into consideration in the evaluation of the quality of higher education. The present study investigating the courses related to science education is believed to contribute to the efforts to adjust the courses in pre-school teacher education programs to European Credit Transfer System (ECTS). 


\section{Geniş Özet}

\section{Giriş}

Okul öncesi dönemde çocuklar öğrenmeye oldukça yatkın olup, merak ve araştırma duyguları üst düzeydedir. Nitelikli bir okul öncesi eğitim için çocukların araştırma ve yaratıcılık düzeylerini destekleyici, sorularına yanıt bulacakları eğitim ortamları oluşturulmalıdır (Aral, Kandır ve Can Yaşar, 2000; EC, 2006; Özbey, 2006). Çevrelerini araştırıp incelemeye başladıkları okul öncesi dönemde çocuklara verilen eğitimin niteliği, onların akademik gelişimlerinin yanı sıra yaşadıkları toplumun değer yargılarını kazanma düzeylerini de etkilemektedir. Bireysel ve grup eğitimine dayalı etkinlikler aracılığıyla, toplumun kültürel özelliklerine uygun davranış alışkanlıklarını kazandıkları, öğrenmeye en açık oldukları bu dönem; kişiliğin temellerinin atıldığı yıllar olarak kabul edilmektedir (Oğuzkan ve Oral, 1997; Ural, 1986).

Eğitim sisteminin ilk basamağını oluşturan okul öncesi dönem, temel eğitime hazırlayıcı bir süreçtir. Okul öncesi eğitim döneminde çocuklar, meraklı araştırıcı ve sorgulayıcıdırlar. Çocukların neden-sonuç ilişkisini kurabilecekleri, meraklarını giderebilecekleri, tahmin etme becerilerinin desteklenebileceği eğitim ortamları hazırlanmalıdır. Merak ve araştırma duygularını geliştirici, zihinsel yetilerini uyarıcı nitelikte olan fen etkinlikleri nitelikli okul öncesi eğitim ortamlarının hazırlanmasına etki etmektedir (Aktaş-Arnas, 2003). Okul öncesi dönemde fen eğitimi, fen bilgilerinin doğrudan aktarılmasından ziyade, çocukların bu bilgileri deneyerek ve yaparak öğrenmelerini esas almaktadır (Aktaş Arnas, 2002a, 2002b).

Fen günlük yaşamımızın bir parçası olarak kabul edilmektedir. Fen eğitimi de çocuklar için anlamlı ve günlük yaşamla ilişkilendirilmiş olarak eğitim programlarıyla bütünleştirilmelidir (Eliason ve Jenkins, 2003; Akt. Balat, 2010). Okul öncesi dönemde uygulanacak eğitim programları çocukların tüm gelişim aşamalarına uygun amaç ve kazanımlar içermelidir. Soru sorma, araştırma yapma, veri toplama ve sorulara cevap arama çalışmalarından oluşan yaparak yaşarak öğrenme süreci bilim öğrenmenin en iyi yolu olarak ifade edilmekte, ayrıca okul öncesi dönem çocuklarla çalışırken yaparak yaşayarak öğrenme sürecinin doğal bir olgu olduğu belirtilmektedir. İyi bir fen eğitiminin temelini de çocukların aktif olarak katıldığı, uyguladığı-yaptığı çalışmalar oluşturmaktadır (Balat, 2010).

Etkili bir fen eğitimi, programların niteliğinin yanı sıra uygulanma süreci ile bir bütündür. Hazırlanan eğitim programlarının başarısı, uygulayıcı konumundaki öğretmenlerin mesleki becerileri ile ilişkilidir. Öğretmenler, okul öncesi eğitim programlarında yer alan amaç ve kazanımların gerçekleştirilmesi için farklı etkinlikler yapmaktadırlar. Çocukları gözlem, araştırma, inceleme ve keşfetmeye yönelten fen etkinlikleri bu etkinliklerden biridir (MEB, 2012). Fen dersinin çocukların gelişimlerine uygun bir şekilde verilmesinde asıl görev öğretmenlere düşmektedir (Kallery, 2004). Okul öncesi dönemdeki çocuklara, nitelikli bir fen eğitiminin verilebilmesi için öğretmenlerin fen eğitiminin kendi yapısı içinde fizik, kimya, biyoloji gibi farklı alanlardaki bilgilerinin yeterli olması gerekmektedir (Kallery, 2004). Illerleyen yıllardaki başarıların temelini oluşturan okul öncesi dönemde verilecek fen eğitimi, çocukların eğitim hayatlarındaki fen dersi başarılarını da etkileyecektir. Çocuklar fen ile ilgili ilk etkinliklere başladıkları okul öncesi eğitim ortamlarında olumsuz deneyimler yaşadıklarında, öğretmenler tarafından yeterli derecede desteklenmediklerinde; eksik bilgiye sahip olup fene yönelik olumsuz tutumlar geliştirebilmektedir. Dolayısıyla okul öncesi öğretmenlerinin fen eğitimine ilişkin bilgi ve yeterlik düzeylerinin incelenmesi, öğrencilerin akademik başarıları ve fene yönelik tutumları üzerinde de belirleyici rol oynamaktadır (Simpson ve Oliver, 1990).

Hayatlarının ilk yıllarında çocuklara nitelikli eğitim ortamlarının sunulması, ülkelerin gelişmişlik düzeylerinde belirleyici rol oynadığından bu dönemde görev alan öğretmenlerin eğitimlerinin niteliği önemlidir. Türkiye ile Avrupa Birliği $(A B)$ üye ülkelerinde okul öncesi öğretmenliği programlarındaki fen eğitimine ilişkin derslerin kredi, sayı, çeşitlilik ve içerik yönünden incelenmesi, Türkiye'de okul öncesi öğretmenliği programlarının değerlendirilmesi açısından önem arz etmektedir. Bulguların, okul öncesi 
öğretmeni yetiştirme sisteminde fen eğitimine yönelik düzenlemelere katkı sağlayacağı, bunun yanı sıra okul öncesi öğretmenliği programında yer alan derslerin Avrupa Kredi Transfer Sistemi (AKTS) ile uyumuna yönelik yapılacak düzenlemelere katkı sağlayacağı düşünülmektedir. Ülkemizde öğretmen yetiştiren kurumların daha iyi standartlara ulaşabilmesi bazı yenilik ve değişimleri gerektirmektedir. Bu değişiklikleri gerçekleştirebilmek için, öncelikle Avrupa Birliği'ne üye olan ülkelerin eğitim sistemlerinin ve politikalarının incelenmesinin fayda sağlayacağı düşünülmektedir. Ancak ülkemizdeki okul öncesi öğretmenliği programlarında yer alan fen eğitimine yönelik derslerin, AB üye ülkeleri ile sayı, kredi ve içerik yönünden karşılaştırmalı bir biçimde incelendiği herhangi bir çalışmaya rastlanmamıştır. Bu nedenle Türkiye'de okul öncesi öğretmeni adaylarının lisans eğitimleri süresince fen eğitimine yönelik aldıkları dersler, bazı $A B$ üye ülkelerindeki okul öncesi öğretmenliği programında yer alan dersler ile karşılaştırmalı bir biçimde incelenmiştir.

\section{Yöntem}

\section{Araştırma Modeli}

Okul öncesi öğretmenliği programlarında yer alan fen eğitimine ilişkin derslerin sayı, içerik, çeşitlilik ve kredileri açısından incelenmesinin amaçlandığı bu çalışmada, var olan durumu belirlemeye yönelik betimsel bir araştırma gerçekleştirilmiştir.

\section{Verilerin Toplanması}

Doküman inceleme yönteminin izlendiği bu çalışmada Türkiye ve $A B$ üye ülkelerin değişkenlere ait bilgilerine "Avrupa Birliği Ajansı (European Agency), Avrupa Eğitim Bilgi Ağı (Eurydice)- Avrupa'da Eğitim Sistemi ve Ulusal Politikalar" kaynaklarından ulaşılmıştır. Bulgular her bir ülkenin yayınladığı "Ulusal Eğitim Sistemlerine Genel Bakış (National System Owerviews)" raporlarında belirtilen yükseköğretim kurumlarının okul öncesi öğretmenliği lisans programlarındaki derslerin incelenmesi sonucunda elde edilmiştir. Bu raporların referans aldıkları üniversitelerin ilgili web sitelerinde yayınladıkları ders programları ve ders içerikleri incelenmiş daha sonra bu değerler, derslerin yer aldıkları dönemleri, sayıları, içerikleri ve kredileri açısından karşılaştırmalı olarak betimlenmiştir.

\section{Verilerin Analizi}

Fen eğitimine ilişkin derslerin belirlenmesi amacıyla ilk olarak Türkiye ve $A B$ üye ülkelerinin "Avrupa Birliği Ajansı (European Agency) web sitesinde her bir ülkenin kendi eğitim sistemine ait ulusal eğitim raporlarının yayınlandığı "Avrupa Eğitim Bilgi Ağı (Eurydice)- Avrupa'da Eğitim Sistemi ve Ulusal Politikalar" kaynaklarına ulaşılmıştır. Her bir ülkenin yayınladığı bu raporlardan "Ulusal Eğitim Sistemlerine Genel Bakış National System Owerviews" yazılı dökümanda referans olarak alınan yükseköğretim kurumlarının ilgili web adresleri belirlenmiştir. Bu web adresleri aracılığıyla online ortamda ulaşılan yükseköğretim kurumlarında lisans düzeyinde eğitim veren programların yer aldığı "eğitim fakülteleri, eğitim-kültür ve toplum fakülteleri, sosyal bilimler ve pedagoji fakülteleri, beşeri ve sosyal bilimler fakülteleri" gibi farklı isimlerle adlandırılan yüksek öğretim kurumlarının "okul öncesi eğitimi, anaokulu eğitimi, erken çocukluk ve aile eğitimi" gibi çeşitlilik gösteren ilgili anabilim dalları bünyesinde bulunan "anaokulu öğretmenliği, okul öncesi eğitimi öğretmenliği, erken çocukluk öğretmenliği" programları belirlenmiştir.

Bu bölümlerde okutulmakta olan dersler "ders programları, alınması zorunlu olan dersler, mezuniyet koşulları, yıllık akademik takvim" gibi bölümler sistematik bir şekilde incelenerek belirlenmiştir. Her bir ülkenin okul öncesi öğretmenliği programı "toplam eğitim süresi, giriş koşulları, mezuniyet için gereken koşullar, zorunlu dersler, ders çeşitliliği, her dersin AKTS kredisi, içeriği, çeşitliliği ve işlenişi" açısından incelenmiş, elde edilen veriler araştırmanın amaçlarına uygun olarak bulgulara dönüştürülmüştür. 
Bulguları oluşturan tüm veriler, ulusal eğitim sistemlerinde referans olarak yer alan yükseköğretim kurumlarına ait okul öncesi öğretmenliği anabilim dallarında, okul öncesi öğretmenliği programlarına ait ders programlarına detaylı olarak yer verildiği yazılı doküman şeklindeki ulusal eğitim raporlarının incelenmesiyle sınırlıdır.

\section{Bulgular}

\section{Türkiye'de Okul Öncesi Öğretmeni Yetiştirme Sistemi}

1739 sayılı Milli Eğitim Temel Kanunu 43. maddesi uyarınca, Türkiye'de okul öncesi öğretmeni yetiştirme görevi yükseköğretim kurumlarınca yürütülmektedir. 1980-1981 öğretim yılında uygulamaya başlanmış 2 yıllık “Anaokulu Öğretmenliği Ön Lisans Programı”, 1991-1992 öğretim yılından itibaren 4 yıllık lisans programı olarak eğitim fakülteleri bünyesinde yer almıştır. Daha sonra adı "Okul Öncesi Öğretmenliği" olarak düzenlenen program, YÖK'ün 1998 yılında eğitim fakültelerinin yeniden yapılandırılması çalışmaları sonucunda, eğitim fakültelerinin İlköğretim Bölümü içinde bir anabilim dalı olarak yer almıştır. Bu düzenleme ile YÖK, gerek kamu gerekse vakıf üniversitelerinde yürütülen okul öncesi öğretmenliği programlarının standart olmasını sağlamıştır. 2012 Yüksek Öğretim Kurulu Öğrenci Seçme ve Yerleştirme Merkezi verilerine göre 45 devlet, 12 vakıf üniversitesi olmak üzere 57 üniversitede okul öncesi öğretmenliği lisans programı bulunmaktadır.

Türkiye'de okul öncesi öğretmenliği programında eş zamanlı model izlenmekte; genel kültür, alan bilgisi ve öğretmenlik meslek bilgisi dersleri bir bütünlük içinde yürütülmektedir. Programa giriş için bir lise diplomasına sahip olmak ve yükseköğretime geçiş sınavından yeterli puan almak gerekmektedir. Öğrenciler dört eğitim-öğretim yılı sonunda, 240 AKTS krediyi tamamlayarak lisans derecesi ile mezun olabilmektedirler (YÖK, 2012).

\section{Türkiye ve AB Üye Ülkelerinde Okul Öncesi Öğretmenliği Programında Yer Alan Fen Eğitimine İlişkin Dersler}

Türkiye'de ve bazı AB üye ülkelerinde okul öncesi öğretmenliği programında yer alan fen eğitimine ilişkin derslerin sayıları ve yıllara göre dağılımına ilişkin bilgiler Tablo 1.'de sunulmaktadır.

Tablo 2.'de belirtildiği gibi ülkelerin okul öncesi öğretmenliği programlarında yer alan fen eğitimi ile ilgili derslerin akademik dönemlere göre dağılımları ve kredilerinde çeşitlilik görülmektedir. Ancak tüm derslerin toplam kredisi içerisinde fen eğitimi ile ilgili derslerin kredi ağırlıkları açısından önemli bir farklılaşma bulunmamaktadır. Genel olarak fen eğitimi ile ilgili derslerin kredilerinin, tüm derslerin kredi ağırlıkları toplamına oranı \%6 ile \%10 arasında değişiklik göstermektedir. Örneğin Avusturya'da lisans düzeyindeki okul öncesi öğretmenliği programında fen eğitimine yönelik 2. yılda her biri 15'er kredi olmak üzere toplam 30 kredilik "Sing, Play and Explore -Şarkı söylemek, Oyun ve Keşfetmek" ve "Health, Nutrition for Children "Çocuk Sağlığı ve Beslenme" dersleri yer alırken bu oran toplam 32 dersin yer aldığı 480 kredilik okul öncesi öğretmenliği lisans programının \%6'sına karşılık gelmektedir. Türkiye'de ise okul öncesi öğretmenliği programında fen eğitimine yönelik 5 ders yer almaktadır. Bu derslerin akademik yıllara göre dağılımı 1. yıl 8 kredilik "Anne Çocuk Sağlığı ve ilk Yardım" ile 5 kredilik "Insan Anatomisi ve Fizyolojisi" dersi; 2. yıl 4 kredilik "Anne Çocuk Beslenmesi" ile 5 kredilik "Yaratıcılık ve Geliştirilmesi" dersleri ve son olarak 3. yı 4 kredilik "Fen Eğitimi" dersleridir. Bu derslerin kredi ağırlıkları toplamı (26 kredi), 240 krediden oluşan programın \%10'una karşılık gelmektedir. 
Nilay KAYHAN ve Didem KILIÇ-Çukurova Üniversitesi Eğitim Fakültesi Dergisi, 43(2), 2014, 83-102

Tablo 1. Türkiye ve Bazı AB Üye Ülkelerinde Okul Öncesi Öğretmenliği Programında Yer Alan Fen Eğitimine ilişkin Ders Sayıları

\begin{tabular}{lccccc}
\hline Ülkeler & $1 . y ı l$ & $2 . y ı l$ & $3 . y ı l$ & $4 . y ı l$ & Toplam \\
\hline Avusturya & - & 2 & - & - & 2 \\
Belçika & - & 1 & - & - & 1 \\
Çek & 3 & - & - & - & 3 \\
Cumhuriyeti & & & & & \\
Danimarka & - & 2 & - & - & 2 \\
Finlandiya & 1 & 1 & - & - & 2 \\
Hollanda & 1 & - & 1 & - & 2 \\
Ispanya & 1 & 1 & - & - & 2 \\
İsveç & 1 & 1 & - & - & 2 \\
İlanda & - & - & 2 & - & 2 \\
Kıbrıs & - & 1 & 1 & - & 2 \\
Litvanya & 1 & 1 & 1 & 1 & 4 \\
Lüksemburg & 1 & 1 & 1 & - & 3 \\
Macaristan & 3 & 1 & 1 & - & 5 \\
Malta & 3 & 2 & - & 2 & 7 \\
Polonya & - & 1 & 1 & - & 2 \\
Portekiz & 1 & 1 & 2 & - & 4 \\
Slovenya & 1 & 1 & 1 & - & 3 \\
Türkiye & 2 & 2 & 1 & - & 5 \\
Yunanistan & 1 & 2 & 1 & - & 4 \\
\hline
\end{tabular}

Tablo 2. Türkiye ve Bazı AB Üye Ülkelerinde Okul Öncesi Öğretmenliği Programında Yer Alan Fen Eğitimine iliş̧kin Derslerin AKTS Kredileri

\begin{tabular}{lccccc}
\hline Ülkeler & 1.yıl & $2 . y \mathrm{ll}$ & $3 . y \mathrm{ll}$ & 4.yıl & AKTS (Toplam) \\
\hline Avusturya & - & 30 & - & - & 30 \\
Belçika & - & 1 & - & - & 1 \\
Çek Cum. & 7 & - & - & - & 7 \\
Danimarka & - & 6 & - & - & 6 \\
Finlandiya & 3 & 3 & - & - & 6 \\
Hollanda & 3 & - & 3 & - & 6 \\
İspanya & 3 & - & 3 & - & 6 \\
İsveç & 30 & 30 & - & - & 60 \\
İlanda & - & - & 30 & - & 30 \\
Kıbris & - & 5 & 5 & - & 10 \\
Litvanya & 5 & 4 & 7 & 3 & 19 \\
Lüksemburg & 3 & 3 & 3 & - & 9 \\
Macaristan & 4 & 2 & 1 & - & 7 \\
Malta & 12 & 8 & - & 8 & 28 \\
Polonya & - & 6 & 1 & - & 7 \\
Portekiz & 10 & 5 & 10 & - & 25 \\
Slovenya & 5 & 7 & 4 & - & 16 \\
Türkiye & 13 & 9 & 4 & - & 26 \\
Yunanistan & 3 & 7 & 3 & - & 13 \\
\hline
\end{tabular}


Ülkelerin okul öncesi öğretmenliği programlarında yer alan fen eğitimine yönelik ders sayıları incelendiğinde Malta'da 7, Türkiye ve Macaristan'da 5, Portekiz'de 4, Çek Cumhuriyeti, Lüksemburg ve Slovenya'da 3; Avusturya, Danimarka, Finlandiya, Hollanda, İspanya, İsveç, İrlanda, Kıbrıs ve Polonya'da 2; Belçika'da ise yalnızca 1 ders olduğu; bu derslerin kredilerinin ise 1-60 arasında farklılaştığı görülmektedir. İrlanda'da 3. sınıfta alınan fen eğitimine ilişkin zorunlu tek bir ders 15 krediden oluşmakta iken İsveç'te okul öncesi öğretmenliği programına devam eden öğrenciler, 1. ve 2. sınıfta her biri 30 kredi olan iki dersi almaktadırlar. Belçika'da ise okul öncesi öğretmenliği programında fen eğitimine yönelik bir dönem okutulan ve 1 krediden oluşan tek ders yer almaktadır. Diğer yandan Çek Cumhuriyeti, Danimarka, Finlandiya, Hollanda, İspanya, Kıbrıs, Litvanya, Lüksemburg, Macaristan, Malta, Portekiz, Slovenya gibi bir çok Avrupa ülkesi ve Türkiye'de okul öncesi öğretmenliği programındaki fen eğitimine ilişkin derslerin kredileri 2-10 aralığında değişmektedir.

Ülkelerin okul öncesi öğretmenliği programlarında yer alan fen eğitimine ilişkin derslerin içeriklerine ilişkin bulgular incelendiğinde Türkiye ve $A B$ üye ülkelerinde okul öncesi öğretmenliği programlarında benzer konu başlıklarından oluşan derslerin, farklı isimlerle yer aldığı belirlenmiştir. Örneğin "sağlık eğitimi ve yaratıcılık" konu başlığı Avusturya'da 2. yıl okutulan "Sing, Play and Explore-Şarkı söylemek, Oyun ve Keşfetmek" ve "Health, Nutrition for Children-Çocuk Sağlığı ve Beslenme" derslerinin her ikisinde de yer almakta iken; Türkiye'de "sağlık eğitimi" konu başlığı "Anne Çocuk Sağlığı ve IIlk Yardım" dersi içeriğinde, "yaratıcılık" konu başlığı ise "Yaratıcılık ve Geliştirilmesi" adı ile programda yer alan zorunlu ders kapsamında okutulmaktadır. Benzer bir özellik "ilk yardım" konu başlığında da görülmektedir. Belçika'da ilk yardım konu başlığı sağlık eğitimi ile birlikte modüler sistemde hazırlanan derste verilmekte iken Türkiye'de ilk yardım konusu "Anne Çocuk Sağlığı ve Ilk Yardım" ders içeriğinde yer alarak işlenmektedir.

Türkiye ve $A B$ üye ülkelerinde okul öncesi öğretmenliği programlarında fen eğitimine ilişkin derslerin "fen eğitiminin ilkeleri, temel kavramlar, keşfetmek, çevre sorunları ve çevre koruma bilincinin kazandırılması, sağlık eğitimi, ilk yardım, teknoloji, bilimsel süreç becerilerinin desteklenmesi, toplum sağlığı, anatomi, ekolojik denge” gibi benzer konular üzerinde yoğunlaştığı görülmektedir. Danimarka, Hollanda, Litvanya ve Malta gibi ülkelerde fen ve teknoloji ilişkisi ile teknolojinin çevreye etkisine yönelik dersler yer alırken; fen eğitiminin önemli bir bileşeni olarak görülen bilimsel süreç becerilerinin desteklenmesine yönelik dersler Macaristan ve Türkiye'de okul öncesi öğretmenliği programlarında zorunlu ders olarak yer almaktadır. Danimarka'da okul öncesi öğretmenliği programı çok kültürlülük ve sosyal destek eğitim felsefesinden etkilenmiştir. "Sağlık eğitimi" ile "fen ve doğa" isimli iki dersin zorunlu olduğu programda, okul öncesi öğretmeni olmak isteyen öğrencilerin mezun olabilmek için farklı kültür ve etnik kökene sahip çocuklarla çalışmak zorunluluğu bulunmaktadır. İspanya ve Portekiz'de ise okul kazalarının önlenmesi amacıyla "çocukta oyun gelişimi, öğrenme ortamında oyun ve ilk yardım" konulu dersler yer almaktadır. Genel olarak derslerin içerikleri incelendiğinde konularda benzerlikler olduğu, Çek Cuhmuriyeti, Finlandiya, İspanya, Litvanya, Macaristan ve Türkiye'de okul öncesi öğretmenliği programının 1. sınıfında öğretmen adaylarının anne-çocuk sağlığı, organizmanın işleyişi, sağlıklı beslenme gibi konuları içeren dersler aldıkları belirlenmiştir. Hollanda, İsveç, Lüksemburg, Malta, Portekiz, Slovenya, Yunanistan'da ise programın ilk yılında yer alan derslerde fen eğitimine yönelik temel ilke ve kavramlar öğretilmektedir. Yaratıcılığın geliştirilmesi ile ilgili fen eğitimine yönelik dersler Avusturya ve Litvanya'da olduğu gibi Türkiye'de de programın ikinci yılında yer almakta iken; Malta'da birinci yılda okutulmaktadır. Yaratıcılık, her bireyde var olan ve insan yaşamının her bölümünde bulunabilen bir yeti, günlük yaşamdan bilimsel çalışmalara dek uzanan geniş bir alanı içine alan süreçler bütünü, bir tutum ve davranış biçimidir (San, 1979; Akt. Ömeroğlu ve Tural, 2001). 
$A B$ ülkeleri ile Türkiye'deki okul öncesi öğretmenliği programında yaratıcılığın geliştirilmesi ders içeriği incelendiğinde öğretmen adaylarının iyi bir gözlemci olabilmeleri için deneyleri ve gezileri günlük programlarında sık sık kullanmaları gerektiği, çocuğun doğal merakını geliştirecek hayvan yetiştirme, bitki yetiştirme, deney yapma gibi araştırma ve inceleme yapmaya yöneltici olmalarının önemi belirtilmiştir. $\mathrm{Bu}$ amaçla yaratıcılık dersi keşfetme ve yaparak yaşayarak öğrenme süreci ile ilişkili olarak fen eğitimi alanında değerlendirilmiştir. Bunun yanı sıra Hollanda, Macaristan ve Portekiz'de fen eğitimine yönelik ders içeriklerinin bilim ve teknoloji ile kültür ilişkisine dayalı olduğu dikkat çekmektedir.

\section{Sonuç, Tartışma ve Öneriler}

Okul öncesi öğretmenlerinin eğitim öğretim sürecinde edindikleri deneyimler mesleki uygulamalarına ve yeterliklerine etki etmektedir. Ancak alan öğretimindeki yeterlikleri için konu alanı yeterliği ön koşul olarak kabul edilmektedir (Garbett, 2003). Bir okul öncesi öğretmeninin bu yeterlikleri kazanabilmesinde eğitim-öğretimi süresince edindiği bilgi, beceri ve tutumlar etkili olmaktadır. Yükseköğretim kurumlarındaki öğretmen eğitim programlarının dersler ve içerikleri yönüyle incelenmesi, aday öğretmenlere kazandırılması gereken yeterlikler açısından önemli görülmektedir.

Türkiye ve bazı $A B$ üye ülkelerinde okul öncesi öğretmenliği programları eğitim süresi, mezuniyet derecesi, derslerin çeşitlilik ve içerikleri açısından benzerlik gösterirken; derslerin toplam AKTS kredileri açısından bazı farklılıklar bulunmaktadır. Hollanda, Portekiz, Slovenya ve Türkiye'de okul öncesi öğretmenliği programında 2-10 AKTS aralığında değişen dersler yer almakta iken; İsveç'te 30'ar kredilik toplam 60 kredilik fen eğitimine ilişkin dersler okutulmaktadır. Diğer yandan Litvanya, Lüksemburg, Macaristan, Malta ve Yunanistan gibi AB üye ülkelerinin çoğunda okul öncesi öğretmenliği programında yer alan fen eğitimine ilişkin ders sayısı arttıkça toplam AKTS kredi ağırlıklarının azaldığı dikkat çekmektedir. Litvanya'da 4 ders toplam 19 AKTS kredisi, Lüksemburg'da 3 ders toplam 9 AKTS kredisi, Macaristan'da 5 ders toplam 7 AKTS kredisi, Malta'da 7 ders toplam 28 AKTS kredisi ve Yunanistan'da 4 ders toplam 13 AKTS kredisidir. İrlanda ve İsveç'te ise fen eğitimine ilişkin derslerin sayıca az (2 şer ders) ancak kredilerinin İrlanda'da 30 AKTS, İsveç'te ise 60 AKTS kredisi olmak üzere daha fazla olduğu belirlenmiştir. Tamamı lisans düzeyinde eğitim veren Türkiye ve $A B$ üye ülkelerinde, öğrenciler okul öncesi öğretmenliği programından 7-9 dönem aralığında toplam 180 veya 240 AKTS krediyi tamamlayarak mezun olabilmektedirler. Mezuniyet için gereken toplam AKTS Litvanya, Lüksemburg, Malta, İspanya, Portekiz ve Türkiye'de 240 AKTS kredisi iken; Yunanistan, İrlanda Macaristan, Slovenya'da 180 AKTS kredisi'dir. Zorunlu derslerin benzer olduğu Çek Cumhuriyeti, Hollanda, İrlanda, Litvanya, Macaristan, Portekiz'de okul öncesi öğretmenliği programından 4 yıllık bir sürede toplam 240 AKTS kredisi ile mezun olabilmekte iken; Yunanistan'da öğrenciler 180 AKTS ile mezun olmaktadırlar. Diğer yandan İsveç'te eğitim süresi 3 yıl olmasına rağmen öğrenciler 210 AKTS kredisi alarak mezun olmaktadırlar.

Okul öncesi öğretmenliği programlarında yer alan fen eğitimine ilişkin derslerin toplam kredi ağırlıkları karşılaştırıldığında Türkiye'de 127 teorik, 48 uygulama olmak üzere toplam 240 kredi olan okul öncesi öğretmenliği lisans programında fen eğitimine yönelik 1. yarıyılda 5 AKTS değerinde "insan Anatomisi ve Fizyolojisi" dersi, 2. yarıyılda "Anne-Çocuk Sağlığı ve Illkyardım" (8 AKTS) dersi, 3. yarıyılda "Anne-Çocuk Beslenmesi" (4 AKTS) ile "Yaratıcılık ve Geliştirilmesi" (5 AKTS) dersleri ve 5. yarıyılda 4 AKTS değerinde "Fen Eğitimi" dersinin yer aldığı belirlenmiştir. Bu derslerin mezuniyet için gerekli toplam kredinin \%10'una karşılık geldiği belirlenmiştir. Türkiye ve $A B$ üye ülkelerinde okul öncesi öğretmenliği programlarında oyun, yaratıcılık ve çevre eğitimi, fen eğitimi ile ilişkili derslerde verilmektedir. Örneğin Slovenya'da ve Avusturya'da ilgili derslerde fen eğitiminin temel ilkelerinin öğretimi, yaratııılık, çevre eğitim, doğa olayları ile ilişkili oyun öğretimini temel almaktadır.

Lisans eğitimi süresince zorunlu derslerin içerikleri, öğretmen adaylarının konu alanlarına yönelik öz yeterlik düzeyleri üzerinde belirleyici olmaktadır. Okul öncesi dönem bireyin temel fen kavramları kazanacağı ve fen ve teknolojiye ilişkin olumlu veya olumsuz tutum geliştirebileceği bir zaman dilimi olduğundan, bu alanda görev yapacak öğretmen adaylarının nitelikli yetiştirilmesi önem taşımaktadır. Bu 
amaçla yükseköğretim kurumlarında eğitim programlarında yer alan derslerin içeriklerinin, bilim ve teknoloji alanlarındaki değişimlere uyumlu, teorik ve uygulama ile paralel, öğretmen adaylarının var olan performanslarını ve yeterlik düzeylerini destekleyici nitelikte hazırlanması önem taşımaktadır (Alabay, 2006). Okul öncesi dönemdeki çocukların eğitimleri konusuna ilişkin bilimsel çalışmaların ortaya koyduğu ortak sonuç çocuklara imkânlar sağlandığında, gelişimlerini en üst noktaya kadar tamamlayabildikleridir. Çocuklara erken yaşlardan itibaren gelişimlerini en verimli şekilde sürdürebilecekleri ortamları sağlamada okul öncesi öğretmenlerine önemli görevler düşmektedir. Okul öncesi dönemde öğrenme ortamlarının yapılandırılmasında, etkili bir fen öğretiminin sağlanabilmesinde öğretmenlerin konu alanı bilgisi kadar tutumları da etkilidir. Programda yer alan derslerin içerik ve kredi düzenlemelerinde disiplinlerarası bir planlama yapılmalı, özellikle öğretmen adaylarının fen, matematik gibi konu alanına yönelik algılarının bu alanlara özgü derslerin sayı, içerik ve işleyiş düzenlemelerinden etkilenebileceği dikkate alınmalıdır. Okul öncesi öğretmenliği programında yer alan derslerin teorik içeriklerinin yanı sıra uygulama ağırıklarının da gözden geçirilmesi gerekmektedir. Okul öncesi öğretmenliği programına devam eden öğrencilere özel alan yeterliklerinin kazandırılması yanı sıra uygulama ağırlıklı, öğrencilerin etkin bir şekilde katılım gösterdiği ve konu alan bilgisini kazanabilecekleri bir lisans eğitim programı düzenlenmelidir. Bu düzenlemeler ulusal ve uluslararası yükseköğretimde nitelik değerlendirme çalışmalarında rol oynamaktadır. Okul öncesi öğretmenliği programlarında yer alan fen eğitimine ilişkin derslerin incelendiği bu çalışmada elde edilen bulguların okul öncesi öğretmenliği programında yer alan derslerin Avrupa Kredi Transfer Sistemi (AKTS) ile uyumuna yönelik yapılacak düzenlemelere katkı sağlayacağı düşünülmektedir. 


\section{References}

Aktaş Arnas, Y. (2002a). Okul öncesi dönemde fen eğitimi. Yaşadıkça Eğitim,76, 4-6.

Aktaş Arnas, Y. (2002b). Okul öncesi dönemde fen eğitiminin amaçları. Çocuk Gelişimi ve Eğitimi Dergisi, $6(7), 1-6$.

Aktaş Arnas, Y. (2003). Fen Eğitimi, küçük bir bilim adamı yetiştirmenin ilk adımları, Çocuk ve Aile, 42-47.

Alabay, E. (2006). İlköğretim okul öncesi öğretmen adaylarının fen ile ilgili özyeterlik inanç düzeylerinin incelenmesi. Yeditepe Üniversitesi Eğitim Fakültesi Dergisi, 7 (2), 1, 30-40.

Alabay, E. (2011). Okul öncesi eğitimde fen programları. In Akman, B., Uyanık-Balat, G., \& Güler-T. (Eds) Okul öncesi dönemde fen eğitimi, 2. Ed., (pp.63-86) Ankara: Pegem A Yayıncılık.

Aral, N., Kandır, A., \& Can Yaşar, M. (2000). Okul öncesi eğitim ve anasınıfı programları. İstanbul: YA-PA Yayınları.

Ayvacı, H. Ş., Devecioğlu, Y., \& Yiğit, N. (2002). Okul öncesi öğretmenlerin fen ve doğa etkinliklerindeki yeterliliklerinin belirlenmesi. V. Ulusal Fen Bilimleri ve Matematik Eğitimi Kongresi, Ankara.

Bilaloğlu, R., Aslan, D., \& Aktaş Arnas, Y. (2008). Okul öncesi öğretmenlerinin fen etkinliklerine ilişkin bilgi düzeylerinin incelenmesi. Milli Eğitim Dergisi, 178, 88-104.

EC (European Commission) (2006). Efficiency and equity in European education and training systems. Communication from the commission to the Council and to the European Parliament, 8.9.2006, COM (2006), 481 final. Retrieved December 20, 2011 from http://ec.europa.eu/education/policies/2010/doc/comm481 en.pdf(20.12.2011).

Garbett, D. (2003). Science education in early childhood teacher education: Putting forward a case to enhance student teachers' confidence and competence. Research in Science Education, 33, 467-481.

Kallery, M. (2004). Early years teachers late concerns and perceived needs in science: An exploratory study. European Journal of Teacher Education, 27 (2), 147-165.

Kallery, M., \& Psillos, D. (2001). Pre-school teachers' content knowledge in science: Their understandings of elementary science concepts and of issues raised by children's questions. International Journal of Early Years Education, 9 (3), 165-177.

MEB. (2008). Okul öncesi öğretmeni özel alan yeterlikleri. Ankara: Öğretmen Yetiştirme ve Eğitimi Genel Müdürlüğü.

MEB. (2012a). Okul öncesi eğitim programı, Temel Eğitim Genel Müdürlüğü, Ankara: Retrieved October 10, 2012 from http://tegm.meb.gov.tr/www/okul-oncesi-egitim-programi-ve-kurul-karari/icerik/54.

MEB. (2012b). Öğretmenliğe başvuru ve atama kılavuzu- Retrieved September, 3, 2012, from http://ikgm.meb.gov.tr/meb iys dosyalar/2012 09/01122258 20122retmenlebavuruveatamakilav uzu 31.08.2012.pdf. (03/09/2012)

Oğuzkan, F., \& Oral, G. (1997), Okulöncesi eğitimi. İstanbul: Milli Eğitim Basımevi.

Osborne, J., \& Simon, S. (1996). Primary science: past and future directions. Studies in Science Education, 27, 99-147.

Özbek, S. (2009). Okul öncesi öğretmenlerinin fen eğitimine ilişkin görüşleri ve uygulamalarının incelenmesi. Unpublished master's thesis. Çukurova Üniversitesi Sosyal Bilimler Enstitüsü, Adana.

Özbey, S. (2006). Okul öncesi eğitim kurumlarında görev yapan öğretmenlerin fen etkinliklerine ilişkin yeterliliklerinin belirlenmesi. Unpublished master's thesis. Gazi Üniversitesi Eğitim Bilimleri Enstitüsü, Ankara.

Simpson, R. D., \& Oliver, J. S. (1990). A summary of major influences on attitude toward and achievement in science among adolescent students, Science Education, 74 (1), 1-18.

Şahin, F. (1996). Okulöncesi öğretmenlerinin fen kavramlarının öğretiminde kullandıkları metotların tespiti. II. Ulusal Eğitim Sempozyumu Bildirileri, İstanbul. 
Şahin, F. (1998). Okul öncesinde fen bilgisi öğretimi. İstanbul: Beta Yayıncılık.

Ural, M. (1986). Ülkemizde okul öncesi eğitimin yeri ve önemi. 4. Ya-Pa Okul Öncesi Eğitim ve Yaygınlaştırılması Semineri, (pp.13-19). Ankara: Ya-Pa Yayınları.

Ural, O., \& Ramazan, O. (2007). Türkiye'de okul öncesi eğitimin dünü ve bugünü. In. S. Özdemir, H. Bacanlı, \& M. Sözer (Eds), Türkiye'de okul öncesi eğitim ve ilköğretim sistemi temel sorunlar ve çözüm önerileri, (pp.11-56). Ankara:Türk Eğitim Derneği.

Uyanık-Balat, G. (2010). Fen nedir ve çocuklar feni nasıl öğrenir?. In B. Akman, G. Uyanık-Balat., \& T. Güler (Eds.) Okul öncesi dönemde fen eğitimi, (pp.1-17). Ankara: Pegem A Yayıncılık.

Yıldırım, A., \& Şimşek, H. (2006). Sosyal bilimlerde nitel araştırma yöntemleri. (5.ed). Ankara: Seçkin Yayınevi.

YÖK (Yükseköğretim Kurulu) (2012a). Yükseköğretim Kurulu, Üniversiteler. Retrieved June, 12, 2013, from http://www.yok.gov.tr/content/view/531

YÖK (Yükseköğretim Kurulu) (2012b). Yükseköğretim Kurulu, Bologna Süreci Retrieved June, 12, 2013 from http://bologna.yok.gov.tr/ 